\title{
REFUGEE PROTECTION IN THE COVID-19 CRISIS AND BEYOND: THE CAPACITY AND LIMITS OF INTERNATIONAL LAW
}

\author{
MICHELLE FOSTER, ${ }^{*}$ HÉLÈNE LAMBERT * AND JANE MCADAM ${ }^{\S}$
}

\begin{abstract}
The current pandemic and concomitant framework of crisis has led to unprecedented restrictions on global movement, and hence on the ability of refugees to seek protection. These measures have been implemented as a matter of urgency on account of the immediacy of the public health challenge, yet risk violating international refugee and human rights law. This experience provides an opportunity to reflect on an equally compelling, although less imminent, threat, namely displacement linked to the impacts of climate change. This article considers these twin challenges and reflects on the capacity and limits of international law to address both crises, while balancing the competing rights and interests at stake. It argues that a key challenge for international law and policy is how to harness the sense of urgency generated by COVID-19 for the long-term 'climate crisis', without resorting to emergency mechanisms of reactive, short-term, restrictive, and exceptional measures.
\end{abstract}

\section{INTRODUCTION}

The global COVID-19 pandemic has been described repeatedly as unprecedented, necessitating emergency measures by states that would ordinarily be unacceptable. Framed as a 'crisis', ${ }^{1}$ its exceptionality has justified special restrictions and exclusions. How an issue is framed matters because 'it determines how a phenomenon is understood and responded to both normatively and pragmatically'. ${ }^{2}$ Indeed, the 'placement of the problem is a necessary founding act'. ${ }^{3}$

One of the most unparalleled and pervasive responses to the COVID-19 public health crisis has been worldwide border closures and travel restrictions. These have curtailed people's

\footnotetext{
* Professor and Director, Peter McMullin Centre on Statelessness, Melbourne Law School, The University of Melbourne, Australia. Email: m.foster@unimelb.edu.au; ORCID iD: 0000-0002-4381-9484.

- Professor of Law, University of Technology Sydney, Australia. Email: helene.lambert@uts.edu.au; ORCID iD:0000-0003-1456-6219.

$\S$ Scientia Professor and Director, Andrew \& Renata Kaldor Centre for International Refugee Law, Faculty of Law, UNSW Sydney, Australia. Email: j.mcadam@unsw.edu.au; ORCID iD: 0000-0002-3999-7843. This article was produced under the auspices of an Australian Research Council ('ARC') Discovery Grant on 'The Concept of "Imminence" in the International Protection of Refugees', DP160100079, and we acknowledge the generous support of the ARC. We are grateful to Hannah Gordon (Juris Doctor, Melbourne Law School) and Katya Harrop, (Juris Doctor candidate, Melbourne Law School) for their editorial assistance.

${ }^{1}$ Charlesworth critiques international law's obsession with 'crisis', arguing that it 'promotes a narrow agenda for international law': Hilary Charlesworth, 'International Law: A Discipline of Crisis' (2002) 65(3) Modern Law Review 377, 386.

2 Jane McAdam, “The Problem of “Crisis Migration"” (2013) 19(3) Australian Journal of Human Rights 7, 8.

${ }^{3}$ Kenneth Hewitt, 'The Idea of Calamity in a Technocratic Age' in Kenneth Hewitt (ed), Interpretations of Calamity from the Viewpoint of Human Ecology (Allen \& Unwin, 1983) 3, 13.
} 
movement across the globe, creating inconvenience for many but potentially life-threatening risks for would-be refugees. The prevention of cross-border movement - which is a threshold requirement for legal recognition as a refugee ${ }^{4}$ - presents a fundamental challenge for the international protection regime.

The mobility challenges posed by the COVID-19 pandemic sound an alarm bell for another context as well. As the Secretary General of the Pacific Islands Forum observed so astutely: 'The COVID-19 public health emergency and its ensuing humanitarian and economic fallout offers us a glimpse of what the global climate change emergency can become - if it is left unchecked and if we do not act now'. ${ }^{5}$ While the risks may be less imminent, they are no less profound.

This article explores what the twin crises of COVID-19 and climate change reveal about the capacity and limits of the international law of protection. As we approach the $70^{\text {th }}$ anniversary of the adoption of the 1951 Convention Relating to the Status of Refugees ('Refugee Convention'), one of the oldest human rights treaties in the post-World War II order, we reflect on its capacity to assist people in need of protection whose movement is restricted. We also consider the tension in broader human rights treaties to accommodate an emergency while also upholding fundamental rights. Central to this analysis is the notion of 'crisis', and how this affects the speed, nature and duration of responses, as well as the capacity for international cooperation and inclusion.

Part II briefly outlines the core challenges posed to protection by the pandemic, noting both positive and negative state practices. Part III examines the international legal framework and its ability to accommodate a state of emergency, considering both the Refugee Convention and the 'International Bill of Rights' (the International Covenant on Civil and Political Rights ('ICCPR') $)^{6}$ and the International Covenant on Economic, Social and Cultural Rights ('ICESCR')). ${ }^{7}$ Part IV then widens our perspective by moving away from the immediacy of the current crisis, to consider the future of international protection in the context of climate change. We posit that a challenge for international law and policy is how to harness the sense of urgency generated by COVID-19 for the long-term 'climate crisis', without resorting to the familiar emergency mechanisms of reactive, short-term, restrictive, and exceptional measures. ${ }^{8}$

\section{THE PANDEMIC AND REFUGEE PROTECTION}

\section{A The Backdrop}

\footnotetext{
${ }^{4}$ Convention Relating to the Status of Refugees, opened for signature 28 July 1951, 189 UNTS 137 (entered into force 22 April 1954) art 1A(2) ('Refugee Convention'), read in conjunction with the Protocol Relating to the Status of Refugees, opened for signature 31 January 1967, 606 UNTS 267 (entered into force 4 October 1967). ${ }^{5}$ Dame Meg Taylor, 'COVID-19 and Climate Change: We Must Rise to Both Crises', Pacific Islands Forum Secretariat (Feature Article, 17 April 2020) <https://www.forumsec.org/2020/04/17/covid-19-and-climatechange-we-must-rise-to-both-crises/>.

${ }^{6}$ Opened for signature 16 December 1966, 999 UNTS 171 (entered into force 23 March 1976) ('ICCPR').

${ }^{7}$ Opened for signature 16 December 1966, 993 UNTS 3 (entered into force 3 January 1976) ('ICESCR').

${ }^{8}$ Crisis narratives 'translate into, and justify, short-term, ad hoc responses instead of pre-emptive, integrated approaches': Elodie Hut et al, 'COVID-19, Climate Change and Migration: Constructing Crises, Reinforcing Borders', Environmental Migration Portal (Blog Post, 2020) $<$ https://environmentalmigration.iom.int/blogs/covid-19-climate-change-and-migration-constructing-crisesreinforcing-borders>. See also Charlesworth (n 1).
} 
By April 2020, it was estimated that around 39\% of the world's population - or some three billion people - were living in states that had closed their borders to all non-citizens and nonresidents, with very limited exceptions. ${ }^{9}$ When combined with measures to prevent citizens from leaving their own country, and the shutdown of much of the global aviation industry, ${ }^{10}$ the limitations on the right to seek asylum ${ }^{11}$ were profound. According to the United Nations High Commissioner for Refugees ('UNHCR'), as at 11 March 2021, 57 states' borders were completely shut, 31 states had no COVID-19 related border restrictions, while 81 had imposed restrictions but made exceptions for asylum seekers. ${ }^{12}$

Australia was a country that restricted movement in both directions, as well as internally through state and territory border closures. Indeed, its prohibition on citizens and permanent residents leaving the country was quite exceptional. ${ }^{13}$ In the first five months of the pandemic, the Commonwealth, states and territories had passed over 800 pieces of legislation, ${ }^{14}$ authorising 'imminent and extraordinary measures' ${ }^{15}$ on account of the 'severe and immediate threat' ${ }^{16}$ posed by the virus. Among the laws were provisions prohibiting entry to ${ }^{17}$ and

\footnotetext{
${ }^{9}$ Phillip Connor, 'More than Nine-in-Ten People Worldwide Live in Countries with Travel Restrictions amid COVID-19', Pew Research Centre (Fact Sheet, 1 April 2020) <https://www.pewresearch.org/facttank/2020/04/01/more-than-nine-in-ten-people-worldwide-live-in-countries-with-travel-restrictions-amid-covid19/>. A smaller number of states shut their borders entirely, including in Central Asia and Ecuador. See also, 'COVID-19 Civic Freedom Tracker', International Center for Not-For-Profit Law (Web Page) <https://www.icnl.org/covid19tracker/?location=\&issue=24\&date=\&type=> (filtered by 'movement').

${ }^{10}$ As at August 2020, there had been a 57-64\% reduction in international passenger numbers: International Civil Aviation Organization, Effects of Novel Coronavirus (COVID-19) on Civil Aviation: Economic Impact Analysis (Report, 12 August 2020) 5.

${ }^{11}$ Universal Declaration of Human Rights, GA Res 217 A (III), UN GAOR, UN Doc A/810 (10 December 1948) art 14(1) ('UDHR'); see also ICCPR art 12.

12 'COVID-19 Platform: Temporary Measures and Impact on Protection', UNHCR (Web Page, 7 March 2021) $<$ https://im.unhcr.org/covid19_platform//> ('COVID-19 Platform').

${ }^{13}$ Chris Uhlmann, 'This Pandemic Has Revealed the Authoritarian Streak in Australian Governments', Sydney Morning Herald (online, 19 August 2020) <https://www.smh.com.au/national/this-pandemic-has-revealed-theauthoritarian-streak-in-australian-governments-20200818-p55mrh.html?btis>; see 'COVID-19 and the Border: Leaving Australia', Department of Home Affairs (Web Page, 28 August 2020) <https://web.archive.org/web/20200830193346/https://covid19.homeaffairs.gov.au/leaving-australia >.

${ }^{14}$ Tim Game, 'The Bar Rises to Meet the Challenges of COVID-19' (Winter 2020) Bar News 4; for details, see 'Coronavirus (COVID-19) Legislation Orders, Directions, Regulations \& Related Resources', Federal Court of Australia (Web Page) <https://www.fedcourt.gov.au/covid19/legislation>. Only a handful of these were primary legislation scrutinised by Parliament. The legislation/instruments referred to below were current as at $11 \mathrm{March}$ 2021.

${ }^{15}$ See, eg, Administrator of the Territory of Christmas Island, Extension of Declaration of State of Emergency (4 March 2021); Administrator of the Territory of Cocos (Keeling) Island, Extension of Declaration of State of Emergency (4 March 2021).

${ }^{16}$ See, eg, Biosecurity (Human Biosecurity Emergency) (Human Coronavirus with Pandemic Potential) Declaration 2020 (Cth) s 6(d), as at 3 March 2021. See also Biosecurity (Human Biosecurity Emergency) (Human Coronavirus with Pandemic Potential) (Overseas Travel Ban Emergency Requirements) Determination 2020 (Cth).

${ }^{17}$ See, eg, Biosecurity (Human Biosecurity Emergency) (Human Coronavirus with Pandemic Potential) (Emergency Requirements) Determination 2020 (Cth) s 5, as at 2 September 2020; Restricting Cruise Ships from Entering Queensland Waters Direction (No 2) 2020 (Qld) s 3.
} 
departures from the country, ${ }^{18}$ interstate travel, ${ }^{19}$ movement into particular areas or venues, ${ }^{20}$ and requirements that people self-isolate and not move about in the community. ${ }^{21}$ All Australian states and territories apart from New South Wales have been declared to be in a 'state of emergency'. 22

\footnotetext{
${ }^{18}$ See, eg, Biosecurity (Human Biosecurity Emergency) (Human Coronavirus with Pandemic Potential) (Overseas Travel Ban Emergency Requirements) Determination 2020 (Cth) s 5.

${ }^{19}$ See, eg, Christmas Island (Coronavirus Emergency - Entry and Quarantine) Direction 2020 (No 3) (Cth); Cocos (Keeling) Islands (Coronavirus Emergency - Entry and Quarantine) Direction 2020 (No 3) (Cth); Public Health (COVID-19 Lord Howe Island) Order 2020 (NSW); Border Restrictions Direction (No 5) 2020 (Qld); Restricted Access to Designated Areas Direction (No 3) 2020 (Qld); Directions in Relation to King Island, Flinders Island and Islands in the Furneaux Group of Islands 2020 (Tas); Quarantine (Closing the Border) Directions 2020 (WA), enacted 5 April 2020. An Emergency Declaration, Travel Ban, and movement restrictions were also put into place for Norfolk Island: see, eg, Norfolk Island, Norfolk Island Government
} Gazette, No 18, 17 April 2020; Norfolk Island Regional Council, 'Recovery Plan in a COVID-19 Environment' (Plan, 2020)

<http://www.norfolkisland.gov.nf/sites/default/files/docs/NIRC/EMNI_MRs/Norfolk\%20Island\%20COVID$19 \% 20$ Recovery\%20Plan.pdf $>$.

${ }^{20}$ See, eg, Public Health (COVID-19 Residential Aged Care Facilities) Order 2020 (NSW); COVID-19 Legislation Amendment (Emergency Measures) Act (No 1) 2020 (NSW) sch 2 cl 2.5, sch 2 cl 2.2; COVID-19 Directions (No 24): Directions for Aged Care Facilities 2020 (NT); Aged Care Direction (No 4) 2020 (Qld); Hospital Visitors Direction (No 3) 2020 (Qld); Emergency Management (Residential Aged Care Facilities No 4) (COVID-19) Direction 2020 (SA); Direction under Section 16 (Residential Aged Care Facilities - No 7) 2020 (Tas); Care Facilities Directions (No 4) 2020 (Vic); Hospital Visitor Directions (No 4) 2020 (Vic); Remote Aboriginal Communities Directions (No 3) 2020 (WA); Visitors to Residential Aged Care Facilities Directions (No 2) 2020 (WA).

${ }^{21}$ See, eg, Public Health (Returned Travellers) Emergency Direction 2020 (No 5) (ACT); Public Health (SelfIsolation) Emergency Direction 2020 (ACT); Public Health (COVID-19 Self-Isolation) Order 2020 (NSW); Public Health (COVID-19 Maritime Quarantine) Order 2020 (NSW); Public Health (COVID-19 Air Transportation Quarantine) Order 2020 (NSW); COVID-19 Directions (No 32): Directions for Territory Border Restrictions 2020 (NT); COVID-19 Directions (No 21): Directions for Potentially Infected Persons 2020 (NT); COVID-19 Directions (No 7): Directions for Infected Persons 2020 (NT); Home Confinement, Movement and Gathering Direction (No 6) 2020 (Q1d); Self-Isolation for Diagnosed Cases of COVID-19 Direction (No 3) 2020 (Qld); Self-Quarantine for Persons Arriving in Queensland From Overseas Direction (No 3) 2020 (Qld); Emergency Management (COVID-19) (Isolation Following Diagnosis or Close Contact) Direction 2020 (SA); Emergency Management (Continuation of Overseas Travel Self-Quarantine) (COVID-19) Direction 2020 (SA); Direction in Relation to Persons Arriving in Tasmania 2020 (Tas); Direction under Section 16 (Stay at Home Requirements - No 5) (Tas); Direction Under Section 16 (Quarantine - No 1) (Tas); Direction under Section 16 (Isolation - No 2) (Tas); COVID-19 Omnibus (Emergency Measures) Act 2020 (Vic) ss 112K, 600M; Direction and Detention Notice (No 4) (Vic); Diagnosed Persons and Close Contacts Directions (No 2) (Vic); Airport Arrivals Direction 2020 (Vic); Cruise Ship Docking Direction 2020 (Vic); Emergency Management Amendment (COVID-19 Response) Act 2020 (WA); Chevron FIFO Worker Directions 2020 (WA); Exempt Traveller (International and Domestic Flight Crew) Approval and Conditions (No 2) 2020 (WA); Isolation (Diagnosed) Directions 2020 (WA); Quarantine and Isolation (Undiagnosed) Directions 2020 (WA).

22 The following measures were current as at 11 February 2021. Australian Capital Territory: Public Health Emergency Declaration (No 1) 2020 (ACT) (declared 16 March 2020) last extended on 19 November 2020 until 17 February 2021 by Public Health (Emergency) Declaration Further Extension (No 12) 2020 (ACT). New South Wales: New South Wales is the only state not to have declared an emergency because the Minister for Health has broad powers to deal with a public health emergency under the Public Health Act 2010 (NSW) s 7. Northern Territory: 'Declaration of Public Health Emergency' in Northern Territory, Government Gazette, No S10, 18 March 2020, last extended a period of 90 days (commencing 23 December 2020) by 'Extension of Operation of Declaration of Public Health Emergency' in Northern Territory, Government Gazette, No S55, 11 December 2020. Queensland: 'Public Health Emergency Order' in Queensland, Queensland Government Gazette, No 25, 31 January 2020, 97, last extended on 17 December 2020 until 31 March 2021 by Public Health (Further Extension of Declared Public Health Emergency: COVID-19) Regulation (No 6) 2020 (Qld). South Australia: Declaration of a Major Emergency 2020 (SA) (declared 22 March 2020), last extended 4 February 2021 until 6 March 2021 by Approval of Extension of a Major Emergency Declaration under Section 232021 
The explosion of laws in this one state (Australia) exemplifies the plethora of legal instruments that emerged globally to contain the spread of the virus by containing mobility. A public health emergency is, of course, one of the few permitted grounds on which the right to free movement and the right to leave one's country can be constrained. ${ }^{23}$ However, as the UNHCR's Assistant High Commissioner for Protection has observed, the 'long-term risk posed by COVID-19 is that the adoption of emergency laws and policies may become entrenched or "baked in"" $24-\mathrm{a}$ risk that is heightened the longer the pandemic lasts. Current modelling suggests that the virus will recur in a number of waves, and there is no reliable prediction of it ending before the global availability of a vaccine or the development of herd immunity. ${ }^{25}$ While the imminent risk posed by COVID-19 may therefore justify restrictions on movement, international law requires that such restrictions be stringently monitored to ensure that they are removed once no longer necessary and proportionate.

\section{B Refugee Law}

The challenges posed to refugee protection by the pandemic are profound. To be a refugee, a person must have crossed an international border. This element is well established in international law, ${ }^{26}$ and a constant reminder of the limits of the refugee definition and international protection. This notion of alienage ${ }^{27}$ is also encapsulated by the principle of nonrefoulement, the cornerstone of the protection regime, which prohibits removal to any place where a person faces a real risk of persecution or other serious harm. ${ }^{28}$ Hence, for refugees,

(SA). Tasmania: 'Declaration of State of Emergency' in Tasmania, Tasmanian Government Gazette, No 21953 , 20 March 2020, 141, as amended by 'Amendment of Declaration of State of Emergency' in Tasmania, Tasmania Government Gazette, No 21 593, 20 March 2020, 141, last extended on 20 November 2020 until 13 February 2021 by Section 15 Extension of Declaration of State of Emergency 2020 (Tas). Victoria: 'Declaration of a State of Emergency' in Victoria, Victoria Government Gazette, No S 129, 16 March 2020, last extended on 29 January 2021 until 26 February 2021 by Extension of Declaration of a State of Emergency 2021 (Vic). Western Australia: Declaration of State of Emergency 2020 (WA) (declared 15 March 2020) last extended 4 February 2021 until 18 February 2021 by Extension of State of Emergency Declaration 2021 (WA). In terms of external territories, see Christmas Island: Declaration of State of Emergency 2020 (Christmas Island) (declared 18 March 2020) last extended on 27 January 2021 until 30 January 2021 (in 72-hour periods only) by Extension of Declaration of State of Emergency 2021 (Christmas Island); Cocos (Keeling) Islands: Declaration of State of Emergency 2021 (Cocos (Keeling) Islands) (declared 18 March 2020) last extended on 27 January 2021 until 30 January 2021 (in 72-hour periods only) by Extension of Declaration of State of Emergency 2021 (Cocos

(Keeling) Islands); Jervis Bay: Declaration of State of Emergency (Jervis Bay Territory) (No 1) 2021 (Jervis Bay), repealing all previous Declarations of a state of emergency.

${ }^{23}$ ICCPR art 12(3).

${ }^{24}$ Gillian Triggs, 'We Can Secure Both Public Health and the Rights of Refugees to Protection', Kaldor Centre for International Refugee Law (Blog Post, 8 April 2020)

$<$ https://www.kaldorcentre.unsw.edu.au/publication/we-can-secure-both-public-health-and-rights-refugeesprotection>.

${ }^{25}$ Kristine A Moore et al, COVID-19: The CIDRAP Viewpoint (Report, 30 April 2020) 5-6

$<$ https://www.cidrap.umn.edu/sites/default/files/public/downloads/cidrap-covid19-viewpoint-part1_0.pdf >.

${ }^{26}$ Refugee Convention art 1(A)(2).

${ }^{27}$ Andrew E Shacknove, 'Who Is a Refugee?' (1985) 95(2) Ethics 274, 283.

${ }^{28}$ See, eg, Refugee Convention art 33; ICCPR arts 6-7. 
'mobility is an essential, even a life-saving act' ${ }^{29}$ and COVID-19 affects refugees 'at the most fundamental level - their ability to seek protection in another country'. ${ }^{30}$

However, faced with a pandemic that 'knows no boundaries', ${ }^{31}$ states have adopted numerous and significant additional emergency measures to slow or halt movement more generally. Border closures have been a common and preferred response by states, followed by health requirements, changes to visa conditions, and entry restrictions for certain nationalities. ${ }^{32} \mathrm{By}$ July 2020, 219 states and territories had implemented 71,589 restrictive measures, predominantly relating to borders and entry. ${ }^{33}$ Further, at least 99 states had made no exception for people seeking asylum. ${ }^{34}$ Search and rescue operations in the central Mediterranean were temporarily suspended, ${ }^{35}$ and UNHCR and International Organization for Migration ('IOM') announced an unprecedented temporary freeze on global resettlement. ${ }^{36}$ While these agencies have since announced the resumption of resettlement departures for refugees, ${ }^{37}$ Australia - the third largest resettlement country - halted its resettlement program in March 2020, with no indication as to when it may resume. ${ }^{38}$

\footnotetext{
${ }^{29}$ Laura Hammond, 'Mobility and Immobility in the Time of Coronavirus: Reflections from Long-Term Study of Migration and Displacement' (Annual Elizabeth Colson Lecture, University of Oxford, 24 June 2020) <https://www.youtube.com/watch?v=DKvO1o9uM9E>.

${ }^{30}$ Harriet Spinks, 'Seeking Asylum in the Time of Coronavirus: COVID-19 Pandemic Effect on Refugees and People Seeking Asylum', Flagpost (Blog Post, 19 May 2020)

<https://www.aph.gov.au/About_Parliament/Parliamentary_Departments/Parliamentary_Library/FlagPost/2020/ May/COVID-19_-_impacts_on_refugees_and_asylum_seekers $>$.

${ }^{31}$ Mailman School of Public Health at Columbia University, Migration and Human Rights Program at Cornell Law School, and the Zolberg Institute on Migration and Mobility, 'Human Mobility and Human Rights in the COVID-19 Pandemic: Principles of Protection for Migrants, Refugees, and other Displaced Persons' (Web Page, 2020) 4 <https://zolberginstitute.org/wp-content/uploads/2020/04/Human-mobility-and-human-rights-inthe-COVID_final-1.pdf > ('Protection Principles'); endorsed by 1,000 legal experts: 'Mobility in the Time of COVID-19', Zolberg Institution on Migration and Mobility (Web Page, 2020)

$<$ https://zolberginstitute.org/covid-19/>.

${ }^{32}$ IOM, 'Global Mobility Restriction Overview: Bi-Weekly Update' (COVID-19 Mobility Impacts Update Series, 9 July 2020) 1 <https://migration.iom.int/system/tdf/reports/DTM-

Covid19\%20Global\%20Overview\%20Output\%2009.07.2020\%20Final_3.pdf?file=1\&type=node\&id=9182>.

${ }^{33}$ Ibid. See also, 'Coronavirus: Travel Restrictions, Border Shutdowns by Country', Al Jazeera (online, 3 June 2020) <https://www.aljazeera.com/news/2020/03/coronavirus-travel-restrictions-border-shutdowns-country200318091505922.html>.

${ }^{34}$ United Nations, COVID-19 and People on the Move (Policy Brief, June 2020) 19

<https://data2.unhcr.org/en/documents/details/76793>; 81 states made no exception as of 11 March 2021: see 'COVID-19 Platform' (n 12).

${ }^{35}$ Hans HP Kluge et al, 'Refugee and Migrant Health in the COVID-19 Response' (2020) 395(10232) The Lancet 1237, 1238.

${ }^{36}$ UNHCR, 'IOM, UNHCR Announce Temporary Suspension of Resettlement Travel for Refugees' (Press Release, 17 March 2020) <https://www.unhcr.org/en-au/news/press/2020/3/5e7103034/iom-unhcr-announcetemporary-suspension-resettlement-travel-refugees.html>.

${ }^{37}$ See UNHCR, 'Joint Statement: UN Refugee Chief Grandi and IOM's Vitorino Announce Resumption of Resettlement Travel for Refugees' (Press Release, 18 June 2020) $<$ https://www.unhcr.org/enau/news/press/2020/6/5eeb85be4/joint-statement-un-refugee-chief-grandi-ioms-vitorino-announceresumption.html>, noting that that the suspension led to the delay in the departure of 'some 10,000 refugees to resettlement countries'.

${ }^{38}$ Spinks (n 30). Persons whose visas were previously approved through the resettlement (humanitarian) program have not been exempted from the travel ban: 'COVID-19 and the Border: Australian Citizens, Permanent Resident or New Zealand Citizens Usually Resident in Australia', Department of Home Affairs (Web Page, 18 December 2020) <https://web.archive.org/web/20210105103653/https://covid19.homeaffairs.gov.au/australian-citizen-orpermanent-resident $>$.
} 
Restrictions on refugees' mobility are not new. Over the past three decades, in particular, states have adopted widespread measures of containment, detention, interception, pushbacks, turnbacks and so on, designed to deter people from seeking asylum in the first place, or to thwart their attempts to do so. ${ }^{39}$ Thus, while the border restrictions imposed on account of COVID-19 are extreme, they are a stark reminder of the extant 'global mobility divide' ${ }^{40}$ Even prior to the pandemic, much of the world's population could not travel freely. The privilege of mobility belongs to relatively few: many people do not hold passports, which also makes visas (and thus many countries) inaccessible. ${ }^{41}$ This necessarily impacts on people's ability to access protection from persecution or other serious harm, whether on account of conflict, general violence or disasters.

Refugees' particular vulnerabilities have been further exacerbated by the impossibility of maintaining physical distancing and other COVID-19 safety measures in overcrowded camps and detention centres. ${ }^{42}$ Movement restrictions have impeded access to livelihoods and access to basic services, ${ }^{43}$ such as social protection, public health, education, child protection, income support, and social networks to manage periods of self-isolation. ${ }^{44}$ In some cases, refugees have been explicitly excluded from them. ${ }^{45}$ For example, in Australia, asylum seekers have been

\footnotetext{
${ }^{39}$ Daniel Ghezelbash, Refuge Lost: Asylum Law in an Interdependent World (Cambridge University Press, 2018) 44-6. See generally, Thomas Spijkerboer, 'The Global Mobility Infrastructure: Reconceptualising the Externalisation of Migration Control' (2018) 20(4) European Journal of Migration and Law 452; Cathryn Costello, 'Refugees and (Other) Migrants: Will the Global Compacts Ensure Safe Flight and Onward Mobility for Refugees?' (2018) 30(4) International Journal of Refugee Law 643. See also Thomas Gammeltoft-Hansen and Nikolas Feith Tan, 'Extraterritorial Migration Control and Deterrence' in Cathryn Costello, Michelle Foster and Jane McAdam (eds), The Oxford Handbook of International Refugee Law (Oxford University Press, forthcoming) ch 27; and Violeta Moreno-Lax, 'Protection at Sea and the Denial of Asylum' in Costello, Foster and McAdam (eds) (n 39) ch 26.

${ }^{40}$ Henley \& Partners, Henley Passport Index and Global Mobility Report (Report, 2019) 30

$<$ https://www.henleypassportindex.com/assets/2019/HPI\%20Global\%20Mobility\%20Report_Final_190104.pdf $>$.

${ }^{41}$ Ibid; Max J Andrucki, 'The Visa Whiteness Machine: Transnational Motility in Post-Apartheid South Africa' in France Winddance Twine and Bradley Gardener (eds), Geographies of Privilege (Routledge, 2013) 121.

${ }^{42}$ Nichole Georgeou and Charles Hawksley (eds), State Responses to COVID-19: A Global Snapshot at 1 June 2020 (Report, 2020) 61-2, 79, 82

<https://researchdirect.westernsydney.edu.au/islandora/object/uws\%3A56288/datastream/PDF/view>. For instance, in Bangladesh as at 16 June 2020, 38 COVID-19 cases among refugee communities had been confirmed and two people had died.; however, it has been noted that noted that testing rates are low and that numbers are likely higher than has been reported: Amy Bainbridge, 'A Coronavirus Crisis is Building Inside Cox's Bazar, the World's Largest Refugee Camp', ABC News (online, 16 June 2020)

<https://www.abc.net.au/news/2020-06-16/rohingya-refugees-coxs-bazar-coronavirus/12356046>. The United Nations has noted that COVID-19 lockdown measures have disrupted supply chains, affecting availability of fresh food to refugee camps in Bangladesh: 'Three Years after Exodus, Rohingya Refugees "More Vulnerable than Ever"', UN News (online, 25 August 2020) <https://news.un.org/en/story/2020/08/1070962>. The pandemic has led to the World Food Programme postponing e-voucher programmes, currently providing food assistance to almost $88 \%$ of the refugees. It had previously hoped to increase support to everyone living in refugee camps by early 2020. Education centres in the camps have been closed since March 2020, resulting in disrupted schooling of more than 300,000 children.

${ }^{43}$ UNHCR, Global COVID-19 Emergency Response (Report, 11 August 2020) 3

<https://reporting.unhcr.org/sites/default/files/11082020_updated\%20UNHCR\%20Global\%20COVID19\%20Emergency\%20Response.pdf> ('Global COVID-19 Emergency Response').

${ }^{44}$ IOM, Integrating Migration into COVID-19 Socio-Economic Response: A Toolkit for Development Partners (Report, August 2020) <https://eea.iom.int/sites/default/files/publication/document/MMICD-ToolkitIntegrating-Migration-COVID-19-Response-August.pdf> ('Integrating Migration'). ${ }^{45}$ Ibid.
} 
denied pandemic-specific social security support. ${ }^{46}$ Yet, as UNHCR has observed, 'the virus does not distinguish between nationals or migrants, and having a two-tiered system in place to access [for example] essential medical service during this health crisis serves no one's interest'. ${ }^{47}$

At the same time, the urgency of the pandemic opened up possibilities for states to respond in more inclusive ways. Indeed, UNHCR noted that 'adaptability' is a sign of a quality asylum system, ${ }^{48}$ and several states continued to register asylum seekers and issue documentation to ensure their legal stay and access to services. ${ }^{49}$ More novel approaches included Portugal's granting of 'temporary citizenship' to all people in its territory whose asylum or residency applications were pending. ${ }^{50}$ Jordan agreed to consider Asylum-Seeker and Refugee Certificates issued by UNHCR as valid until the end of 2020, even if the certificates technically expired sooner. ${ }^{51}$ Malta, Azerbaijan, and the United Kingdom implemented 'innovative approaches', such as allowing online applications for asylum, appeals, and/or documentation. ${ }^{52}$ Canada announced that it would provide a pathway to permanent residence for asylum seekers who had been working in the health-care sector during the COVID-19 pandemic, provided that various conditions were met. ${ }^{53}$ In Ireland and Latvia, older refugees and those with underlying medical conditions were guaranteed increased medical attention. ${ }^{54}$ A number of states, including Belgium, Mexico, Spain, Switzerland, United Kingdom, and the United States, began to release asylum seekers from detention to reduce the number of people in closed facilities, ${ }^{55}$ and to establish alternatives, particularly for children, families, and more vulnerable refugees. ${ }^{56}$

\footnotetext{
46 'Information about COVID-19 and Social Security', Refugee Council of Australia (Web Page, 25 April 2020) $<$ https://www.refugeecouncil.org.au/social_security_faq_covid-19/>.

${ }^{47}$ Lena Kainz, 'As COVID-19 Slows Human Mobility, Can the Global Compact for Migration Meet the Test for a Changed Era?', Migration Policy Institute (Commentary, April 2020)

<https://www.migrationpolicy.org/news/covid19-global-compact-migration-faces-test>.

48 'The Role of the Global Compact on Refugees in the International Response to the COVID-19 Pandemic', UNHCR (Article, 29 July 2020) 2 <https://globalcompactrefugees.org/article/role-global-compact-refugeesinternational-response-covid-19-pandemic > ('The Role of the Global Compact').

${ }^{49}$ By 5 August 2020, UNHCR reported that national asylum systems were fully operational in 57 states and partially operational in 53: UNHCR, Global COVID-19 Emergency Response (n 43 ) 3.

50 'Coronavirus: Portugal Grants Temporary Citizenship Rights to Migrants', Euronews (online, 29 March 2020) <https://www.euronews.com/2020/03/29/coronavirus-portugal-grants-temporary-citizenship-rights-tomigrants>.

${ }^{51}$ UNHCR, Global COVID-19 Emergency Response (n 43) 3.

${ }^{52}$ UNHCR Regional Bureau for Europe, Practical Recommendations and Good Practice to Address Protection Concerns in the Context of the COVID-19 Pandemic (Guidance, 15 April 2020) 3-4.

${ }^{53}$ Immigration, Refugees and Citizenship Canada, 'Pathway to Permanent Residency Recognizes Exceptional Service of Asylum Claimants on Front Lines of COVID-19 Pandemic' (News Release, 14 August 2020) $<$ https://www.canada.ca/en/immigration-refugees-citizenship/news/2020/08/pathway-to-permanent-residencyrecognizes-exceptional-service-of-asylum-claimants-on-front-lines-of-covid-19-pandemic.html>.

${ }^{54}$ UNHCR Regional Bureau for Europe, Practical Recommendations and Good Practice to Address Protection Concerns in the Context of the COVID-19 Pandemic (Guidance, 15 April 2020) 5.

55 Ibid 7; 'COVID-19 Global Immigration Detention Platform: Mexico', Global Detention Project (Web Page, 3 June 2020) <https://www.globaldetentionproject.org/covid-19-immigration-detention-platform>; 'Judge Orders US to Free Migrant Children from Family Detention, Citing Virus Spread', The Guardian (online, 27 June 2020) <https://www.theguardian.com/us-news/2020/jun/27/judge-orders-us-to-free-migrant-children-fromfamily-detention-citing-virus-spread?CMP=Share_iOSApp>.

${ }^{56}$ Inter-Agency Standing Committee, COVID-19: Focus on Persons Deprived of Their Liberty (Interim Guidance, 27 March 2020) 3 <https://interagencystandingcommittee.org/system/files/2020-

11/IASC \%20Interim\%20Guidance\%20on\%20COVID-19\%20-

\%20Focus\%20on\%20Persons\%20Deprived\%20of\%20Their\%20Liberty_0.pdf>.
} 
Finally, across the globe, refugee-led initiatives provided vital community-based services and support. ${ }^{57}$

\section{INTERNATIONAL REFUGEE LAW IN A STATE OF EMERGENCY}

As is clear from the above, notwithstanding some positive state practice, the pandemic has posed challenges to the core of refugee protection, which is predicated on mobility. Since a person cannot meet the international definition of 'refugee' until they leave their country, the right to leave is paramount. Further, since almost no state provides for an 'asylum seeker visa' to be lodged from outside the putative state of asylum, movement to seek and obtain protection is crucial.

\section{A The Right to Leave}

Despite movement being central to the Refugee Convention, the treaty itself is silent on the right to leave. That right is instead found in article 13(2) of the Universal Declaration of Human Rights ('UDHR') ${ }^{58}$ and article $12(2)$ of the widely ratified ICCPR, which provides that '[e]veryone shall be free to leave any country, including his own' ${ }^{59}$ Given its wide ambit, the right is not confined to those wishing to flee their countries of origin but extends to refugees in intermediary countries or otherwise en route to seeking asylum.

There is a large literature on states' attempts to obfuscate the right to leave and, with it, the right to seek asylum. ${ }^{60}$ The current crisis, however, raises the pertinence of permitted exceptions to the right to leave in a more pressing manner than may previously have been the case. Article 12(3) of the ICCPR provides that the right to leave 'shall not be subject to any restrictions except those which are provided by law, are necessary to protect national security, public order (ordre public), public health or morals or the rights and freedoms of others, and are consistent with the other rights recognized in the present Covenant' ${ }^{61}$

This right may also be the subject of derogation under article 4(3) of the ICCPR, although the United Nations Human Rights Committee ('UN Human Rights Committee') has warned states

\footnotetext{
${ }^{57}$ For examples of many initiatives worldwide, see 'Global Compact on Refugees: Responding to COVID-19 in the Spirit of the Global Compact on Refugees', UNHCR (Web Page)

$<$ https://globalcompactrefugees.org/refugees-covid-19-

crisis\#: :text=Call\%20for\%20COVID\%2D19\%20Good,generous\%20host\%20countries\%20and\%20communiti es>; Mustafa Alio et al, 'By Refugees, for Refugees: Refugee Leadership during COVID-19, and Beyond', Kaldor Centre for International Refugee Law (Blog Post, 20 April 2020)

$<$ https://www.kaldorcentre.unsw.edu.au/publication/refugees-refugees-refugee-leadership-during-covid-19-andbeyond>; Alexander Betts, Evan Easton-Calabria and Kate Pincock, 'Refugee-Led Responses in the Fight against COVID-19: Building Lasting Participatory Models’ [2020] 64 (June) Forced Migration Review 73, 734.

${ }^{58} U D H R(\mathrm{n} 11) \operatorname{art} 13(2)$.

${ }^{59}$ ICCPR art 12(2).

${ }^{60}$ UDHR (n 11) art 14; Vladislava Stoyanova, 'The Right to Leave Any Country and the Interplay between Jurisdiction and Proportionality in Human Rights Law' (2020) 32(3) International Journal of Refugee Law 403. See also Andrew Wolman, 'The Role of Departure States in Combating Irregular Migration in International Law: An Historical Perspective' (2019) 31(1) International Journal of Refugee Law 30; Mariagiulia Giuffré and Violeta Moreno-Lax, "The Rise of Consensual Containment: From "Contactless Control" to "Contactless Responsibility” for Forced Migration Flows' in Satvinder Singh Juss (ed), Research Handbook on International Refugee Law (Edward Elgar, 2019).

${ }^{61}$ ICCPR art 12(3).
} 
that in the context of the pandemic, derogation is not necessary in relation to rights such as article 12 of the ICCPR that already facilitate states to 'attain their public health or other public policy objectives by invoking the possibility to restrict certain rights' ${ }^{62}$ It is important to note that while some other widely-ratified human rights treaties permit similar restrictions on the right to leave, ${ }^{63}$ article 18(1)(c) of the Convention on the Rights of Persons with Disabilities ('CRPD'), ratified by 182 states parties, permits no limitations on or derogation from the right to leave. ${ }^{64}$ This has been largely overlooked in the discussion of the pandemic, yet it is estimated that between 15 and 30\% of refugees may meet the treaty's definition of 'persons with disability'; ${ }^{65}$ hence, it is not an insignificant issue.

In terms of article 12(3)'s limitation, given that public health is a legitimate restriction, and assuming that relevant measures are imposed by law, an analysis of state practice turns on the question of necessity, ${ }^{66}$ proportionality, ${ }^{67}$ and consistency of the measure with other ICCPR rights. To this end, blanket prohibitions or limitations rarely meet these requirements. As international law experts recently observed in the context of COVID-19 mobility restrictions:

Where necessary to protect public health, border closures should be subject to exceptions for compelling humanitarian and compassionate needs and that ensure that a State's international obligations can be respected (including the right to seek and enjoy asylum) ${ }^{68}$

Ogg rightly notes that prohibiting exit in the context of asylum may violate the 'right to life (article 6(1) ICCPR) and the right to be free from torture or cruel, inhuman or degrading treatment or punishment (article 7 ICCPR)' where a person is at risk of such harm within their own state. ${ }^{69}$ Of course, a practical issue arises as to the efficacy of humanitarian exceptions to a prohibition on flight where the state is the persecutor and yet also needs to grant permission to leave.

\section{B Protection against Refoulement}

\footnotetext{
${ }^{62}$ Human Rights Committee, Statement on Derogations from the Covenant in Connection with the COVID-19 Pandemic, UN Doc CCPR/C/128/2 (24 April 2020) [2(c)] ('Statement on Derogation'). See also Human Rights Committee, General Comment No 29: States of Emergency (Article 4), $72^{\text {nd }}$ sess, $1950^{\text {th }} \mathrm{mtg}$, UN Doc CCPR/C/21/Rev.1/Add.11 (31 August 2001, adopted 24 July 2001) [5] ('General Comment No 29'). ${ }^{63} \mathrm{See}$, eg, Convention on the Rights of the Child, opened for signature 20 November 1989, 1577 UNTS 3 (entered into force 2 September 1990) art 10(2).

${ }^{64}$ Convention on the Rights of Persons with Disabilities, opened for signature 13 December 2006, 2515 UNTS 3 (entered into force 3 May 2008) art 18(1)(c) ('CRPD'). See also 'Status of Treaties: Convention on the Rights of Persons with Disabilities’, United Nations Treaty Collection (Web Page, 29 June 2020) <https://treaties.un.org/Pages/ViewDetails.aspx?src=TREATY\&mtdsg_no=IV-15\&chapter=4>; there are 173 state parties to the ICCPR: 'Status of Treaties: International Covenant on Civil and Political Rights', United Nations Treaty Collection (Web Page, 29 June 2020)

$<$ https://treaties.un.org/Pages/ViewDetails.aspx?chapter=4\&clang=_en\&mtdsg_no=IV-4\&src=IND> .

${ }^{65}$ Mary Crock et al, The Legal Protection of Refugees with Disabilities: Forgotten and Invisible? (Edward Elgar, 2017) 4-5; CRPD art 1.

${ }^{66}$ ICCPR art 12(3).

${ }^{67}$ Human Rights Committee, General Comment No 29 (n 62) [4].

68 'Protection Principles' (n 31) principle 4.

${ }^{69}$ Kate Ogg, 'COVID-19 Travel Bans: The Rights to Seek Asylum When You Cannot Leave Your Homeland', Kaldor Centre for International Refugee Law (Blog Post, 16 April 2020)

$<$ https://www.kaldorcentre.unsw.edu.au/publication/covid-19-travel-bans-right-seek-asylum-when-you-cannotleave-your-homeland>.
} 
In lieu of a positive and enforceable right to asylum, protection against refoulement is regarded as the fundamental norm of refugee protection. There is widespread agreement that it has attained the status of customary international law, and there is a strong case for its recognition as jus cogens. ${ }^{70}$

Under article 33 of the Refugee Convention, the primary obligation is framed widely: a state may not return 'in any manner whatsoever' a refugee to the 'frontiers of territories where his life or freedom would be threatened' ${ }^{71}$ Near-universal support exists for its extraterritorial application, ${ }^{72}$ meaning that it is relevant to 'externalisation' and containment practices that have been strengthened during the crisis. Most relevantly, however, the absolute ban imposed by many states on non-citizens' entry, without any exception for asylum seekers, and the concomitant pushback and return policies implemented by some states during the crisis (eg Greece to Turkey, Malta to Libya, and the United States to Mexico), ${ }^{73}$ clearly implicate article 33.

Unlike its equivalent in the Convention against Torture and Other Cruel, Inhuman or Degrading Treatment or Punishment (' $C A T$ ') ${ }^{74}$ and the $\operatorname{ICCPR},{ }^{75}$ the prohibition against refoulement in article 33(1) is not absolute. No state may make a reservation in relation to article 33 of the Refugee Convention, ${ }^{76}$ but article 33(2) provides that:

The benefit of the present provision may not, however, be claimed by a refugee whom there are reasonable grounds for regarding as a danger to the security of the country in which he is, or who, having been convicted by a final judgment of a particularly serious crime, constitutes a danger to the community of that country.

As an exception to a fundamental norm, this provision must be read narrowly. On its own terms, it is not relevant to the pandemic since a public health risk can neither come within the concepts 'danger to the security of the country' nor 'danger to the community' (and the latter in any event only applies in the case of a conviction). As UNHCR has emphatically stated, '[d]enial of access to territory without safeguards to protect against refoulement cannot be

\footnotetext{
${ }^{70}$ Cathryn Costello and Michelle Foster, 'Non-Refoulement as Custom and Jus Cogens: Putting the Prohibition to the Test' (2015) 46 Netherlands Yearbook of International Law 273.

${ }^{71}$ Refugee Convention art 33(1). The principle is broader in international human rights law, for instance under Convention against Torture and Other Cruel, Inhuman or Degrading Treatment or Punishment, opened for signature 10 December 1984, 1465 UNTS 85 (entered into force 26 June 1987) art 3 ('CAT'); ICCPR arts 6-7.

${ }^{72}$ Elihu Lauterpacht and Daniel Bethlehem, 'The Scope and Content of the Principle of Non-Refoulement: Opinion' in Erika Feller, Volker Türk and Frances Nicholson (eds), Refugee Protection in International Law: UNHCR's Global Consultations on International Protection (Cambridge University Press, 2003) 87, 149-50; see also 'Summary Conclusions: The Principle of Non-Refoulement' in Feller, Türk and Nicholson (eds) (n 72) $178-9$.

${ }^{73}$ Daniel Ghezelbash, 'COVID-19 and the End of Asylum', Kaldor Centre for International Refugee Law (Blog Post, 11 June 2020) <https://www.kaldorcentre.unsw.edu.au/publication/covid-19-and-end-asylum>. See also Elspeth Guild and Kathryn Allinson, 'The Challenges in Covid19 Times for Refugee Determination and Accessing Protection', Refugee Law Initiative (Blog Post, 28 April 2020) $<$ https://rli.blogs.sas.ac.uk/2020/04/28/the-challenges-in-covid19-times-for-refugee-determination-andaccessing-protection/>; León Castellanos-Jankiewicz, 'COVID-19 Symposium: US Border Closure Breaches International Refugee Law’, Opinio Juris (Blog Post, 3 April 2020) <opiniojuris.org/2020/04/03/covid-19symposium-us-border-closure-breaches-international-refugee-law/>.

${ }^{74} C A T$ art 3.

${ }^{75}$ ICCPR arts 4(2), 6-7. See also Human Rights Committee, General Comment No 29 (n 62) [7].

${ }^{76}$ See Refugee Convention art 42(1).
} 
justified on the grounds of any health risk'. ${ }^{77}$ Further, article 33(2) clearly envisages an individuated assessment; blanket prohibitions cannot be justified. ${ }^{78}$

The notion that an emergency may impact on refugee rights is not new. Significant global events producing large-scale movements have raised the question whether states can suspend obligations in situations of 'mass influx' or other equally challenging contexts, particularly in the Global South, which disproportionately bears responsibility for $85 \%$ of the world's refugees. ${ }^{79}$ Yet, even in that context, the obligation to respect non-refoulement is held to be sacrosanct. ${ }^{80}$

An often-overlooked provision in the Refugee Convention is article 9, which provides:

Nothing in this Convention shall prevent a Contracting State, in time of war or other grave and exceptional circumstances, from taking provisionally measures which it considers to be essential to the national security in the case of a particular person, pending a determination by the Contracting State that that person is in fact a refugee and that the continuance of such measures is necessary in his case in the interests of national security.

This 'rather vague' provision has rarely been analysed in detail, particularly regarding its contemporary meaning. ${ }^{81}$ Commentators have suggested that article 9 could be enlivened by 'grave instances of cold war, international crisis calling for certain internal precautions, or a state of emergency'; ${ }^{82}$ a situation bordering on war; ${ }^{83}$ or the threat of terrorism. ${ }^{84}$ The drafting records show that the term 'grave and exceptional circumstances' was intended to capture the grey area between a 'national emergency' (considered to be too narrow) and 'national security' (considered to be too broad). ${ }^{85}$

At first blush, it seems plausible to argue that a global pandemic could amount to a 'grave and exceptional circumstance', even if this was not specifically contemplated by the drafters. A more difficult question is whether it would come within the narrower language of 'national security in the case of a particular person' (which further conditions the objective to be pursued by any restrictive measures). This narrow language is not coincidental: Hathaway explains that ' $[\mathrm{t}] \mathrm{he}$ drafters of the Convention considered, but did not adopt, an all-embracing power of

\footnotetext{
${ }^{77}$ UNHCR, 'Key Legal Considerations on Access to Territory for Persons in Need of International Protection in the context of the COVID-19 Response' (Summary Paper, 16 March 2020) 2 [6] $<$ https://www.refworld.org/docid/5e7132834.html>.

${ }^{78}$ See ibid. See also Vincent Chetail, 'Crisis Without Borders: What Does International Law Say about Border Closure in the Context of Covid-19?' (2020) 2 Frontiers in Political Science Article 606307:1-6, 3-4.

${ }^{79}$ UNHCR, Global Displacement: Forced Migration in 2019 (Report, 18 June 2020) 2.

${ }^{80}$ Jean-François Durieux and Jane McAdam, 'Non-Refoulement through Time: The Case for a Derogation Clause to the Refugee Convention in Mass Influx Emergencies' (2004) 16(1) International Journal of Refugee Law 4.

${ }^{81}$ Ulrike Davy, 'Article 91951 ' in Andreas Zimmermann (ed), The 1951 Convention Relating to the Status of Refugees and Its 1967 Protocol: A Commentary (Oxford University Press, 2011) 781, 783.

82 Ibid 792, citing Nehemiah Robinson, Convention Relating to the Status of Refugees: Its History, Contents and Interpretation (Institute for Jewish Affairs, 1953) 96, which draws on Conference of Plenipotentiaries on the Status of Refugees and Stateless Persons, Summary Record of the Sixth Meeting, $6^{\text {th }} \mathrm{mtg}$, UN Doc A/CONF.2/SR.6 (4 July 1951) $13 \mathrm{ff}$ ('Conference of Plenipotentiaries').

${ }^{83}$ Davy (n 81) 792 citing Atle Grahl-Madsen, Commentary on the Refugee Convention 1951, Articles 2-11, 1337 (Division of International Protection of the United Nations High Commissioner for Refugees, 1997) 27.

${ }^{84}$ Davy (n 81) 793, citing James C Hathaway, The Rights of Refugees under International Law (Cambridge University Press, $2^{\text {nd }}$ ed, 2021) 292.

${ }^{85}$ Davy (n 81) 787, 792, citing Conference of Plenipotentiaries (n81).
} 
derogation in time of national crisis' ${ }^{86}$ The drafters also rejected the inclusion of additional reasons for invoking 'provisional measures', such as 'public order' concerns. ${ }^{87}$ It would therefore be difficult to justify measures to contain the pandemic as matters of 'national security'. ${ }^{88}$ In any event, provisional measures cannot include refoulement, and any measures need to be applied on an individual basis: article 9 is not a true derogation clause, ${ }^{89}$ but rather permits provisional measures 'in the case of a particular person' ${ }^{90}$ Indeed, Davy argues that 'there are strong reasons to doubt that measures under [article] $9 \ldots$ are permissible under human rights law, ${ }^{91}$ and that human rights law has rendered the provision nugatory. ${ }^{92}$

In sum, there is no justification for blanket violations of the principle of non-refoulement in the pandemic crisis.

\section{Refugee Rights}

As outlined in Part II, serious human rights issues have been raised in connection with the treatment of asylum seekers and refugees during the pandemic, ranging from inadequate public health measures, especially in closed detention, through to exclusion from welfare support.

When it comes to the movement of refugees within a country, the Refugee Convention protects freedom of movement for those who are lawfully present. ${ }^{93}$ States may restrict the movement of refugees who have arrived without prior authorisation, but only where such restrictions do not amount to penalties ${ }^{94}$, are 'necessary', and only 'until their status in the country is regularized or they obtain admission into another country'. 95

This is supplemented by the ICCPR's protection of freedom of movement, ${ }^{96}$ prohibition of arbitrary detention, ${ }^{97}$ and its requirement that 'all persons deprived of their liberty shall be treated with humanity and with respect for the inherent dignity of the human person' ${ }^{98}$ Immigration detention, including of asylum seekers, is still common and states that do not ensure detainees have appropriate protection against COVID-19 are arguably in violation of these obligations. Indeed, the UN Human Rights Committee has emphasised in relation to the pandemic that states

may not derogate from their duty to treat all persons, including persons deprived of their liberty, with humanity and respect for their human dignity, and must pay special attention to the adequacy

\footnotetext{
${ }^{86}$ James C Hathaway, The Rights of Refugees under International Law (Cambridge University Pres, $2^{\text {nd }}$ ed, 2021) 292 ('The Rights of Refugees under International Law: Second Edition').

${ }^{87}$ Ibid 297.

${ }^{88}$ Ibid 297-8.

${ }^{89}$ See Durieux and McAdam (n 80) 16, fn 66.

${ }^{90}$ UNHCR, The Refugee Convention, 1951: The Travaux Préparatoires Analysed with a Commentary by Dr

Paul Weis (1990) 59.

${ }^{91}$ Davy (n 81) 802.

92 Ibid 803.

${ }^{93}$ See Refugee Convention art 26.

94 Ibid art 31(1).

${ }^{95}$ Ibid art 31(2).

${ }^{96}$ ICCPR art $12(1)$.

${ }^{97}$ Ibid art $9(1)$.

${ }^{98}$ Ibid art 10(1).
} 
of health conditions and health services in places of incarceration, and also to the rights of individuals in situations of confinement ... ${ }^{99}$

As mentioned above, while some states have released asylum seekers and refugees from detention as a precautionary measure, this has at times resulted from specific court orders. ${ }^{100}$ However, in states without a bill of rights or domestically-incorporated international human rights obligations (such as Australia), litigation to seek the release of immigration detainees due to concerns about COVID-19 has so far had very limited success. ${ }^{101}$ Indeed, in Australia, the numbers of people held in immigration detention has risen - not declined - in recent months,${ }^{102}$ and their conditions have been made more challenging due to the suspension of the immigration detention visitor program on 24 March 2020, which in Victoria, has been further expanded to include a bar on the personal delivery or collection of 'gifts, property and other items' to persons in detention. ${ }^{103}$

Denial of access to welfare and other social support directly engages the Refugee Convention. It requires states to accord to 'lawfully staying' refugees the 'same treatment with respect to public relief and assistance as is accorded to their nationals', ${ }^{104}$ and 'the same treatment as is accorded to nationals' in respect of '[s]ocial security', including unemployment benefits. ${ }^{105}$ These rights may not be suspended pursuant to article 9 where a person has been found to be a refugee, and in any event cannot be suspended on a group basis. ${ }^{106}$ The question of whether a refugee is 'lawfully staying' is more complex, yet this term must be given an autonomous meaning independent of the policies of certain states, such as the provision of only 'temporary' visas to recognised refugees. ${ }^{107}$

\footnotetext{
${ }^{99}$ Human Rights Committee, Statement on Derogation (n 62) [2(e)].

${ }^{100} \mathrm{See}$, eg, in the United Kingdom, $R(S M L) v$ Secretary of State for the Home Department [2020] 5 WLUK 148. Shah notes that in the United States, as at the end of June 2020, 'more than 100 lawsuits have been filed in federal courts seeking relief on behalf of non-citizens in ICE custody at heightened risk of serious illness or death due to the virus': Aditi Shah, 'The Role of Federal Courts in Coronavirus-Related Immigration Detention Litigation', Lawfare (Blog Post, 29 June 2020) <lawfareblog.com/role-federal-courts-coronavirus-relatedimmigration-detention-litigation>.

${ }^{101}$ In BNL20 v Minister for Home Affairs [2020] FCA 1180, a diabetic detainee over the age of 65, and in poor health, was said to be at a heightened risk of contracting COVID-19: at [6] (Murphy J). It was argued that this warranted injunctive relief requiring the Minister not to hold the person in Melbourne Immigration Transit Accommodation (MITA): at [3] (Murphy J). At [103] Murphy J ordered that: 'the respondent, as soon as reasonably practicable but in any event no later than $1.00 \mathrm{pm}$ on the 13 August 2020, [would] cease to detain the applicant at the [Melbourne Immigration Transit Accommodation centre] until further order'. However, this did not result in release into community but rather transfer to Yongah Hill Immigration Detention Centre: BNL2O v State Emergency Coordinator and Commissioner of Police [2020] WASC 315.

102 See Department of Home Affairs, Immigration Detention and Community Statistics (Report, 31 May 2020) 4, 6-7 <https://www.homeaffairs.gov.au/research-and-stats/files/immigration-detention-statistics-31-may2020.pdf>, noting an increase of 41 people in immigration detention centres and facilities in Australia since the last reporting period in the previous month.

103 'COVID-19 and the Border: Immigration Detention', Department of Home Affairs (Web Page, 11 August 2020) <https://web.archive.org/web/20201015071511/https://covid19.homeaffairs.gov.au/immigrationdetention>.

${ }^{104}$ Refugee Convention (n 4) art 23.

${ }^{105}$ Ibid art 24(1)(b).

${ }^{106}$ We note that Davy argues that article 9 does authorise large-scale actions, but this appears to be inconsistent with the text itself ('in the case of a particular person ...'): at (n 81) 800.

${ }^{107}$ Hathaway, The Rights of Refugees under International Law: Second Edition (n 86) 213-15.
} 
Under the ICESCR, the non-discrimination obligation applies 'to everyone including nonnationals, such as refugees, asylum-seekers, stateless persons [and] migrant workers ${ }^{108}$ and is not subject to progressive realisation. Further, the ICESCR has no derogation clause. ${ }^{109}$ As such, the Committee on Economic, Social and Cultural Rights has urged the treaty's 171 state parties, as 'a matter of urgency', to adopt 'special, targeted measures, including through international cooperation, to protect and mitigate the impact of the pandemic on vulnerable groups such as ... refugees'. ${ }^{110}$ Hence, there is no justification for excluding asylum seekers, refugees, or stateless persons from protective economic and social measures during the pandemic; indeed, as Scheinin points out, some human rights treaties, such as the CRPD, 'call for heightened protection in situations of crisis'. ${ }^{111}$

Finally, the ICCPR contains a freestanding equality and non-discrimination clause in article 26 which 'is not limited to those rights which are provided for in the Covenant'. ${ }^{112}$ While it is possible for states to derogate from some ICCPR rights '[i]n time of public emergency which threatens the life of the nation and the existence of which is officially proclaimed' ${ }^{113}$ this power is closely circumscribed. Any derogation measures must: (1) only extend to what is strictly required by the exigencies of the situation; (2) not be inconsistent with states' other obligations under international law; and (3) not involve 'discrimination solely on the ground of race, colour, sex, language, religion or social origin'. ${ }^{114}$ An 'unprecedented' number of states have lodged formal notices of derogation in response to COVID-19, ${ }^{115}$ but none has purported to justify the exclusion of vulnerable groups, such as asylum seekers, from special safety net measures. Indeed, such an attempt would be unlawful in light of the non-discrimination requirement, pertinent to derogation, which includes 'race' and 'social origin'.

In all circumstances, derogations are envisaged as 'exceptional and temporary' ${ }^{116}$ Reflecting the principle of proportionality, they are limited 'to the extent strictly required by the exigencies of the situation', and 'must, as far as possible, be limited in duration, geographical coverage and material scope'. ${ }^{117}$ The predominant objective is to restore 'a state of normalcy where full respect for the Covenant can again be secured', ${ }^{118}$ which means that, where possible,

\footnotetext{
${ }^{108}$ Committee on Economic, Social and Cultural Rights, General Comment No 20:

Non-Discrimination in Economic, Social and Cultural Rights, UN ESCOR, 42 ${ }^{\text {nd }}$ sess, Agenda Item 3, UN Doc E/C.12/GC/20 (2 July 2009) 9 [30].

${ }^{109}$ But see ICESCR art 4 limitation.

${ }^{110}$ Committee on Economic, Social and Cultural Rights, Statement on the Coronavirus Disease (COVID-19)

Pandemic and Economic, Social and Cultural Rights, UN ESCOR, UN Doc E/C.12/2020/1 (17 April 2020, adopted 6 April 2020) 3 [15].

${ }^{111}$ Martin Scheinin, 'COVID-19 Symposium: To Derogate or Not to Derogate?', Opinio Juris (Blog Post, 4 June 2020) <http://opiniojuris.org/2020/04/06/covid-19-symposium-to-derogate-or-not-to-derogate/> (emphasis in original), citing $C R P D$ art 11.

${ }^{112}$ Human Rights Committee, CCPR General Comment No 18: Non-discrimination, $37^{\text {th }}$ sess, UN Doc HRI/GEN/1/Rev.9 (Vol. I) (10 November 1989) 197 [12].

${ }^{113}$ ICCPR art 4(1).

114 Ibid.

${ }^{115}$ Scheinin (n 111)

${ }^{116}$ Human Rights Committee, General Comment No 29 (n 62) [2].

${ }^{117}$ Human Rights Committee, Statement on Derogation (n 62) [2(b)].

118 Human Rights Committee, General Comment No 29 (n 62) [1]. Given the risk of human rights abuses, derogations should be regularly reviewed. See, eg, Commission on Human Rights, Status of the International Covenants on Human Rights: Note Verbale Dated 24 August 1984 from the Permanent Representative of the Netherlands to the United Nations Office at Geneva Addressed to the Secretary General, UN ESCOR, $41^{\text {st }}$ sess, Agenda Item 18, UN Doc E/CN.4/1985/4 (28 September 1984) annex ('The Siracusa Principles on the Limitation and Derogation Provisions in the International Covenant on Civil and Political Rights') 8 [55]: 'The national
} 
'States parties should replace COVID-19-related measures that prohibit activities relevant to the enjoyment of rights under the Covenant with less restrictive measures'. ${ }^{119}$ Additional derogation notifications are required if a state extends the duration of a state of emergency. ${ }^{120}$

The analysis above suggests that the problem lies not with the normative framework: the Refugee Convention, despite its longevity, is particularly attentive to the need to account for the legitimate interests of states in delivering refugee protection, including in the context of emergencies, and human rights treaties similarly permit flexibility. Yet, the invocation of the language of crisis appears to have given many states carte blanche to act in violation of international refugee law.

\section{PERMANENT 'CRISIS’? CLIMATE CHANGE, DISPLACEMENT, AND INTERNATIONAL LAW}

Crises are not just one-off events but can encompass slower processes of change or deterioration as well. ${ }^{121}$ Understanding this is important, because it lifts our gaze beyond the here and now to contemplate policy responses over the longer-term. The challenge is to overcome the human tendency to give 'overwhelmingly higher importance ... to events or effects which will take place in the short term compared to the long term, ${ }^{, 22}$ - an approach that effectively guarantees future emergencies and their attendant restrictions on human rights. How might the urgency generated by COVID-19 help to drive more measured, considered and sustainable policies to address the 'slow motion' crisis of climate change? ${ }^{123}$

If we think about crisis in an extended timeframe, we can identify interventions now that could avert future shocks. Many of the measures taken during the pandemic, for instance, are relevant to preparing for the impacts of climate change: 'the need to identify vulnerable populations, assess the capacity of public health systems, develop and invest in preparedness measures, and emphasise community resilience and equity'. ${ }^{124}$ But whereas COVID-19 has resulted in unprecedented measures of containment, the impacts of climate change will contribute to widespread displacement. Disasters - many of which are exacerbated by climate change ${ }^{125}-$ accounted for $75 \%$ of all new global internal displacement (24.9 million people) in $2019 .{ }^{126}$ Cross-border movement is anticipated to rise as well, especially since internal displacement

constitution and laws governing states of emergency shall provide for prompt and periodic independent review by the legislature of the necessity for derogation measures'.

${ }^{119}$ Human Rights Committee, Statement on Derogation (n 62) [2(b)].

${ }^{120}$ Ibid [2(a)].

${ }^{121}$ McAdam, "The Problem of "Crisis Migration"” (n 2) 11-12.

${ }^{122}$ Simon Bushell et al, 'Strategic Narratives in Climate Change: Towards a Unifying Narrative to Address the Action Gap on Climate Change' (2017) 28 Energy Research \& Social Science 39, 40.

${ }^{123}$ RT Pierrehumbert, 'Climate Change: A Catastrophe in Slow Motion' (2006) 6(2) Chicago Journal of International Law 573.

${ }^{124}$ Nick Watts et al, 'The 2020 Report of the Lancet Countdown on Health and Climate Change: Responding to Converging Crises' (2021) 397(10269) The Lancet 129, 131.

${ }^{125}$ For a detailed overview, see Jane McAdam et al, Fridtjof Nansen Institute, International Law and Sea-Level Rise: Forced Migration and Human Rights (Report No 1, 2016).

${ }^{126}$ Internal Displacement Monitoring Centre ('IDMC'), 2020 Global Report on Internal Displacement (Report, 2020) 1 <https://www.internal-displacement.org/sites/default/files/publications/documents/2020-IDMC-

GRID.pdf $>$. Since there are no global estimates of the numbers of people displaced by slow-onset hazards, these disaster figures are 'very conservative': IDMC, 2018 Global Report on Internal Displacement (Report, 2018$) 52$ <https://www.internal-displacement.org/global-report/grid2018/downloads/2018-GRID.pdf>. 
may transform into displacement across borders if people cannot find safety and security in their own country. ${ }^{127}$

Existing international protection mechanisms offer an incomplete and imperfect solution for those seeking to escape the longer-term impacts of climate change. There are a number of reasons for this, ${ }^{128}$ including that some effects will take years to manifest at a sufficiently harmful level to satisfy the requisite thresholds in international refugee law and international human rights law. ${ }^{129}$ The challenge for international lawyers - and international law - is whether those bodies of law can evolve dynamically to offer solutions, as they have done historically as 'living instruments' of protection.

Certainly, as understandings of the nature of mobility in the context of climate change and disasters have improved, our analysis of the capacity of existing frameworks to respond has become more nuanced. ${ }^{130}$ At the same time, however, approaching displacement solely in light of extant protection frameworks - or even in terms of a treaty-based regime - 'necessarily constrains our thinking, both conceptually and pragmatically'. ${ }^{131}$ As Fisher, Scotford and Barritt have argued, 'the international treaty process is seen as the ultimate panacea', ${ }^{132}$ but there are many reasons why this alone will not provide a solution for those on the move. ${ }^{133}$ Addressing displacement related to the impacts of climate change requires a holistic, multidisciplinary, and multi-sectoral approach, which is best approached through a 'toolkit' response that encompasses disaster risk reduction, climate change adaptation, humanitarian protection, migration, and planned relocation. ${ }^{134}$

For instance, in late 2019, the UN Human Rights Committee accepted in principle that it is unlawful for states to send people to places where the impacts of climate change expose them to life-threatening risks or cruel, inhuman, or degrading treatment. ${ }^{135}$ However, in the matter at hand, the evidence 'did not establish that [the complainant] faced a risk of an imminent, or

${ }^{127}$ See Nansen Initiative, Agenda for the Protection of Cross-Border Displaced Persons in the Context of Disasters and Climate Change (Report, 2015) vol 1, 39 [99]; IDMC, 2019 Global Report on Internal Displacement (Report, 2019) $41<$ https://www.internaldisplacement.org/sites/default/files/publications/documents/2019-IDMC-GRID.pdf>; IDMC, 2017 Global Report on Internal Displacement (Report, 2017) 9 <https://www.internal-displacement.org/globalreport/grid2017/pdfs/2017-GRID.pdf>.

${ }^{128}$ See Jane McAdam, 'Swimming against the Tide: Why a Climate Change Displacement Treaty is Not the Answer' (2011) 23(1) International Journal of Refugee Law 1 ('Swimming against the Tide').

${ }^{129}$ For a detailed analysis, see Jane McAdam, Climate Change, Forced Migration, and International Law (Oxford University Press, 2012).

${ }^{130}$ See, eg, Matthew Scott, Climate Change, Disasters and the Refugee Convention (Cambridge University Press, 2020); Sanjula Weerasinghe, UNHCR, 'In Harm's Way: International Protection in the Context of Nexus Dynamics between Conflict or Violence and Disaster or Climate Change' (Research Paper No PPLA/2018/05, Division of International Protection, United Nations High Commissioner for Refugees, December 2018).

${ }^{131}$ See discussion in Jane McAdam, 'From the Nansen Initiative to the Platform on Disaster Displacement: Shaping International Approaches to Climate Change, Disasters and Displacement' (2016) 39(4) University of New South Wales Law Journal 1518, 1539.

${ }^{132}$ Liz Fisher, Eloise Scotford, and Emily Barritt, 'Why Understanding the Legally Disruptive Nature of Climate Change Matters', OUPblog (Blog Post, 22 April 2015) <https://blog.oup.com/2015/04/legallydisruptive-nature-of-climate-change/>.

${ }^{133}$ See McAdam, 'Swimming against the Tide' (n 128).

${ }^{134}$ See Nansen Initiative (n 127).

${ }^{135}$ Human Rights Committee, Views Adopted by the Committee under Article 5 (4) of the

Optional Protocol, Concerning Communication No 2728/2016, 127 th sess, UN Doc CCPR/C/127/D/2728/2016 (24 October 2019) ('Teitiota v New Zealand'). 
likely, risk of arbitrary deprivation of life upon return to Kiribati'. ${ }^{136}$ This was despite the Committee's acknowledgment that sea-level rise was 'likely to render the Republic of Kiribati uninhabitable', potentially within ten to 15 years. ${ }^{137}$ At present, there was insufficient evidence to show that the complainant would 'be unable to grow food or access potable water' or would 'face life-threatening environmental conditions', or that 'the Government of Kiribati had failed to take programmatic steps to provide for the basic necessities of life, in order to meet its positive obligation to fulfill the author's right to life'. ${ }^{138}$ The Committee recognised that conditions in Kiribati 'may become incompatible with the right to life with dignity before the risk is realized', ${ }^{139}$ thus tacitly acknowledging that people should not have to wait until their lives are imminently threatened before they are eligible for protection. ${ }^{140}$ However, it did not provide guidance as to when such a point of incompatibility might be reached. ${ }^{141}$

This underscores the need for proactive policies to help build resilience within affected communities and provide lawful opportunities for movement. While the current rate of global warming means that some displacement is inevitable, ${ }^{142}$ the scale of displacement - and attendant economic, social and human costs - could be radically reduced if strategic policy measures were taken now. A World Bank Report posits that robust mitigation and adaptation measures could cut global internal displacement by almost two-thirds by $2050 .{ }^{143}$ Indeed, mitigation might be understood as the climate change equivalent of a COVID-19 vaccine. In addition, disaster risk reduction, increased opportunities for lawful migration, more systematic humanitarian responses to displacement, and selective planned relocations could help avert future displacement and enable people to make real choices about whether they stay in their homes, or move elsewhere. As the United Nations Office for Disaster Risk Reduction has estimated, there could be a 60 -fold return for each dollar spent on preparing for disasters. ${ }^{144}$

The climate crisis is an unfolding process, and interventions must be contemplated over longer timeframes, with new combinations of institutional actors, partnerships, and sustainable funding models. Indeed, without such interventions, the climate crisis 'could prove far lengthier and far more disruptive than what we currently see with the coronavirus'. ${ }^{145}$ The challenge lies in generating support for policy change now to avert devastating consequences in

\footnotetext{
${ }^{136}$ Ibid 10 [9.6].

${ }^{137}$ Ibid 11-12 [9.12]. This endorsed the earlier reasoning of the tribunal and courts in New Zealand (which had heard Mr Teitiota's original claim), that such risks were too speculative to give rise to a protection need at the present time, since Kiribati, assisted by the international community could still 'take affirmative measures to protect and, where necessary, relocate its population'.

138 Ibid 10 [9.6].

${ }^{139}$ See ibid 11 [9.11].

${ }^{140}$ In a dissenting view, one Committee member noted that it would 'be counterintuitive to the protection of life, to wait for deaths to be very frequent and considerable; in order to consider the threshold of risk as met': ibid annex 1, 14 [5], individual opinion of Muhumuza (dissenting), referring also to the main Committee, ibid 9 [9.4].

${ }^{141}$ Analysed further in Jane McAdam, 'Protecting People Displaced by the Impacts of Climate Change: The UN Human Rights Committee and the Principle of Non-Refoulement' (2020) 114(4) American Journal of International Law 708.

${ }^{142}$ Kanta Kumari Rigaud et al, World Bank Group, Groundswell: Preparing for Internal Climate Migration (Report, 2018) xxv.

${ }^{143}$ Ibid xxi, 110.

${ }^{144}$ United Nations Officer for Disaster Risk Reduction, Global Assessment Report on Disaster Risk Reduction (Report, 2015) ix.

${ }^{145}$ Dickon Pinner, Matt Rogers, and Hamid Samandari, McKinsey \& Company, 'Addressing Climate Change in a Post-pandemic World', McKinsey Quarterly (Web Page, 7 April 2020) <https://www.mckinsey.com/businessfunctions/sustainability/our-insights/addressing-climate-change-in-a-post-pandemic-world\#>.
} 
the future, heeding the advice of scientific and other experts. Whereas with COVID-19, 'the consequences from inaction can be seen relatively quickly, as hospitals are overwhelmed by patients infected several weeks ago', with climate change, 'it will take decades to see the full extent of the damage'. ${ }^{146}$ On the one hand, this longer timeframe offers an opportunity for greater international cooperation towards a coherent response than emergency (and often exclusionary) measures allow. On the other hand, it may (and often does) mean that the crisis is perceived as a problem of the future alone, rather than one that is already having far-reaching human rights consequences.

\section{CONCLUSION}

Movement and non-movement are not black and white. As some state practice during the pandemic has shown, mobility may be restricted, but still permitted. Quarantine and testing can reduce the risk of virus transmission, ${ }^{147}$ enabling people in some of the most vulnerable circumstances to be assisted.

This article has shown the continuing relevance of the Refugee Convention (and other human rights treaties) in the context of emergencies such as COVID-19, in particular, by acknowledging the legitimate interests of states in refugee protection. However, when faced with a crisis that is unfolding over a longer timeframe, such as climate change, the question is whether this body of law will evolve dynamically beyond emergency measures to greater international cooperation, without losing the sense of urgency and making it a problem for the future alone. It is also important that the narrative of crisis does not lead to paralysis because the policy challenges are perceived as insurmountable. ${ }^{148}$ For this reason, emphasising proactive measures that can avert future catastrophes - as detailed in the preceding section may engender a more solutions-oriented approach.

As the UNHCR has noted, it is only by respecting human rights that 'we will build better responses for the emergency today and solutions for recovery in the longer term'. ${ }^{149}$ This requires greater international collaboration, responsibility-sharing and cooperation, as promised by states when they adopted the twin Global Compacts on Refugees and Migration in late 2018. ${ }^{150}$ To date, however, these commitments have not withstood the pandemic crisis, despite efforts by the UNHCR, IOM, and others to show how these instruments can assist, rather than hinder, responses. ${ }^{151}$ Whether this is a temporary aberration or hardens into a permanent pattern remains to be seen. COVID-19 has demonstrated that a 'large-scale, comprehensive response' is 'the only way to withstand and manage any future unprecedented

\footnotetext{
${ }^{146}$ Andrew Kliewer, 'Climate Change is Coronavirus in Slow Motion', Age of Awareness (Web Page, 27 April 2020) <https://medium.com/age-of-awareness/climate-change-is-coronavirus-in-slow-motion-b8932f8e2905>.

${ }^{147}$ Even Australia, with some of the most restrictive COVID-19 border controls, has agreed to allow 200 workers from Vanuatu to fly to the Northern Territory for the mango harvest, given labour shortages within Australia. Employers agreed to pay for the cost of the workers' 14-day quarantine: Kath Sullivan and Matt Brann, 'Federal Government Set to Allow Fruit Pickers from Vanuatu into Australia Despite Coronavirus Border Closure', ABC News (online, 31 July 2020) <https://www.abc.net.au/news/2020-07-31/governmentvanuatu-pick-fruit-coronavirus-borders/12509316>.

${ }^{148}$ McAdam, "The Problem of "Crisis Migration"” (n 2) 23.

149 'The Role of the Global Compact' (n 48) 2.

${ }^{150}$ United Nations, Report of the United Nations High Commissioner for Refugees: Part II Global Compact on Refugees, UN Doc A/73/12 (Part II) (2 August 2018); Global Compact for Safe, Orderly and Regular Migration, GA Res 73/195, UN GAOR, 73 ${ }^{\text {rd }}$ sess, Agenda Items 14 and 119, UN Doc A/RES/73/195 (11 January 2019).

${ }^{151}$ See, eg, 'The Role of the Global Compact' (n 48); IOM, Integrating Migration (n 44) ii, 2.
} 
health and climate crisis', and that we do, in fact, have 'the technology, scientific understanding, financial means and human resourcefulness' needed to address it. ${ }^{152} \mathrm{We}$ can only hope, therefore, that the United Nations Secretary-General's ambition for COVID-19 to offer an opportunity to 'reimagine human mobility' ${ }^{153}$ comes to be exemplified by protection, and not exclusion.

152 Robert Metzke, 'Climate Action Must Stay Top of the Global Agenda as We Emerge from COVID-19', World Economic Forum (Article, 22 May 2020) <https://www.weforum.org/agenda/2020/05/climate-action-topglobal-agenda-covid-19/>.

${ }^{153}$ António Guterres, 'The COVID-19 Crisis is an Opportunity to Reimagine Human Mobility', United Nations (Web Page, 3 June 2020) <https://www.un.org/en/coronavirus/covid-19-crisis-opportunity-reimagine-humanmobility>. 